Note

\section{Rapid Purification of Streptomyces griseus Trypsin by Immobilized Rice Bran Trypsin Inhibitor}

\author{
Misao Tashiro, ${ }^{*}$ Nobuo Sugihara, ${ }^{* *}$ \\ Zensuke MAKI* and Masao KANAMORI**
}

\section{*Department of Food Science, Faculty of Living Science, Kyoto Prefectural University, Kyoto 606, Japan \\ **Department of Agricultural Chemistry, Faculty of Agriculture, \\ Kyoto Prefectural University, Kyoto 606, Japan}

Received July 18,1980

Pronase, a commercial preparation of Streptomyces griseus protease, contains several proteinases and peptidases. ${ }^{1)}$ Among them, only one proteinase resembles bovine trypsin in its substrate specificity, response to inhibitors and physico-chemical properties. ${ }^{2 \sim 5}$ ) The purification of this enzyme, S.G. trypsin, has been performed in several ways, $\left.{ }^{2,5} \sim 12\right)$ among which various affinity chromatography techniques, simple and rapid purification methods, were included. However, the purity of S.G. trypsin obtained by these simple methods was not quite satisfactory. We ourselves, however, have purified a trypsin inhibitor from rice bran, and have reported that the rice bran trypsin inhibitor (RBTI) inhibits only trypsin among serine-proteases. ${ }^{13)}$ Therefore, it is very likely that immobilized RBTI selectively binds to S.G. trypsin in Pronase on affinity chromatography.

Enzyme activity toward BAEE or ATEE as substrates was determined by the procedure described by Narahashi ${ }^{\mathrm{i}}$ with a slight modification, in a pH-stat (RTS 622, Radiometer) at $25^{\circ} \mathrm{C}$ under nitrogen gas stream. The reaction mixture contains $0.1 \mathrm{M} \mathrm{KCl}, 0.02 \mathrm{M} \mathrm{CaCl}_{2}$ and $10 \mathrm{~mm}$ BAEE or ATEE adjusted to $\mathrm{pH} 8.0$. One unit of esterase activity is defined as the amount of enzyme which hydrolyzes $1 \mu \mathrm{mol}$ substrate per minute under the conditions described above. BAPA hydrolytic activity was measured according to the method by Erlanger $e t$ al. ${ }^{14)}$ with a slight modification. The reaction was carried out at $37^{\circ} \mathrm{C}$ with a substrate concentration of $0.5 \mathrm{mM}$ in $0.1 \mathrm{M}$ Tris- $\mathrm{HCl}$ buffer, $\mathrm{pH} 8.0$, containing $0.01 \mathrm{M} \mathrm{CaCl}$. Exopeptidase activities were measured with the substrates of $10 \mathrm{~mm} \mathrm{Z-Gly-Leu,} 2 \mathrm{~mm} \mathrm{Bz}$-Gly-Arg and $2.5 \mathrm{~mm}$ Leu-
Gly by the ninhydrin method of Yemm and Cocking. ${ }^{15)}$ Concentration of S.G. trypsin in the solution was calculated from its absorption coefficient, $E_{1 \% \mathrm{~m}}^{1 \%}=17.3$ (at $280 \mathrm{~nm}$ ), for pure enzyme. ${ }^{5 \text { ) }}$

Thirty $\mathrm{mg}$ of RBTI prepared in our laboratory was immobilized by a conventional procedure ${ }^{16)}$ using $\mathrm{CNBr}$ activated Sepharose 4B ( $3 \mathrm{~g}$ of dry gel, Pharmacia) and the immobilized RBTI was packed into a column $(0.8 \times 18 \mathrm{~cm})$. The column was pre-equilibrated with $0.05 \mathrm{M}$ Tris- $\mathrm{HCl}$ buffer, $\mathrm{pH} 8.0$, containing $0.2 \mathrm{M} \mathrm{KCl}$ and $0.02 \mathrm{M}$ $\mathrm{CaCl}_{2}$. One hundred $\mathrm{mg}$ (dry material) of Pronase-P (Kaken Chemical $\mathrm{Co}$.) dissolved in the above buffer was immediately applied to the column. The column was washed with the same buffer and then developed with $\mathrm{pH}$ gradient from $0.05 \mathrm{~m}$ Tris- $\mathrm{HCl}$ buffer, $\mathrm{pH} 8.0$, containing $0.2 \mathrm{M} \mathrm{KCl}$ and $0.02 \mathrm{M} \mathrm{CaCl}_{2}(60 \mathrm{ml})$ to $0.05 \mathrm{M} \mathrm{Na}$-acetate$\mathrm{HCl}$ buffer, $\mathrm{pH} 3.0$, containing $0.2 \mathrm{M} \mathrm{KCl}$ and $0.02 \mathrm{M} \mathrm{CaCl}_{2}$ $(60 \mathrm{ml})$, followed by washing with $0.01 \mathrm{M} \mathrm{HCl}$ containing $0.02 \mathrm{M} \mathrm{CaCl}_{2}$. The elution profile is shown in Fig. 1. At pH 8.0, some proteins in Pronase were firmly adsorbed to the

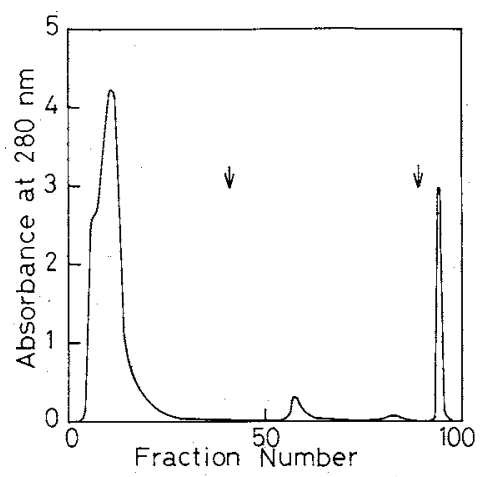

FIG. 1.. Affinity Chromatography of Pronase-P on a RBTI-Sepharose Column $(0.8 \times 18 \mathrm{~cm})$.

Elution buffers were successively changed.

1. $0.05 \mathrm{M}$ Tris- $\mathrm{HCl}, \mathrm{pH} 8.0$, containing $0.2 \mathrm{M} \mathrm{KCl}$ and $0.02 \mathrm{M} \mathrm{CaCl}_{2}(100 \mathrm{ml})$.

2. $\mathrm{pH}$ gradient; $0.05 \mathrm{~m}$ Tris- $\mathrm{HCl}, \mathrm{pH} 8.0$, containing $0.2 \mathrm{M} \mathrm{KCl}$ and $0.02 \mathrm{M} \mathrm{CaCl}_{2}(60 \mathrm{ml})-0.05 \mathrm{M} \mathrm{Na}$-acetate$\mathrm{HCl}, \mathrm{pH} 3.0$, containing $0.2 \mathrm{M} \mathrm{KCl}$ and $0.02 \mathrm{M} \mathrm{CaCl}_{2}$ $(60 \mathrm{ml})$.

3. $0.01 \mathrm{M} \mathrm{HCl}$ containing $0.02 \mathrm{M} \mathrm{CaCl}_{2}$.

Flow rate was $20 \mathrm{~m} 1 / \mathrm{hr}$ and fractions of $2.4 \mathrm{ml}$ were collected. For the maintenance of the enzyme activity, each fraction had previously contained $0.2 \mathrm{ml}$ of $0.6 \mathrm{M}$ $\mathrm{Na}$-acetate buffer, $\mathrm{pH}$ 5.5. The arrows indicate replacement of the eluting solutions.

Abbreviations: BAEE, $\alpha$ - $N$-benzoyl-L-arginine ethyl ester hydrochloride; ATEE, $N$-acetyl-L-tyrosine ethyl ester monohydrate; BAPA, $\alpha$-N-benzoyl-DL-arginine-p-nitroanilide hydrochioride; Z-Gly-Leu, carbobenzoxy-glycyl-Lleucine; Bz-Gly-Arg, $\alpha$-N-benzoyl-glycyl-L-arginine; Leu-Gly, L-leucyl-glycine; NPGB, $\quad p$-nitrophenyl- $p$ guanidinobenzoate hydrochloride. 
Table I. BaEE and ATEE Hydrolytic Activities of Pronase AND S.G. TRYPSIN FraCtion

\begin{tabular}{|c|c|c|c|c|c|}
\hline & \multirow{2}{*}{$\begin{array}{l}\text { Protein } \\
(\mathrm{mg})^{*}\end{array}$} & \multicolumn{2}{|c|}{$\begin{array}{l}\text { Total activity } \\
\text { (units) }\end{array}$} & \multicolumn{2}{|c|}{$\begin{array}{l}\text { Specific activity } \\
\text { (units/mg protein) }\end{array}$} \\
\hline & & BAEE & ATEE & BAEE & ATEE \\
\hline Pronase & 63.2 & 1030 & 460 & 16.3 & 7.28 \\
\hline S.G. trypsin fraction & 5.88 & 911 & 1.94 & 155 & 0.330 \\
\hline
\end{tabular}

* Determined spectrophotometrically.

immobilized inhibitor affinity column. During the $\mathrm{pH}$ gradient, two minor peaks were eluted, and the following elution with the $0.01 \mathrm{M} \mathrm{HCl}$ solution led to a major peak. No BAPA hydrolytic activity was observed in the unadsorbed peak and two minor peaks. The major peak was found to have the hydrolytic activity toward BAPA. This fraction was collected and regarded as a S.G. trypsin preparation. Table I shows BAEE and ATEE hydrolytic activities for Pronase and the S.G. trypsin fraction. Total BAEE hydrolytic activity of the fraction accounted for about $90 \%$ of that of starting Pronase. The specific activity of the S.G. trypsin fraction, 155 BAEE units/mg preotein, was about 10 times higher than that of Pronase, and fully corresponded to the specific activity of the most purified preparation of S.G. trypsin $(150 \sim 170$ units $/ \mathrm{mg}$ protein) obtained by ion-exchange chromatography. ${ }^{5)}$ Furthermore, the enzyme preparation purified by this affinity chromatography had little hydrolytic activity toward ATEE and no hydrolytic activity toward Z-GlyLeu, Bz-Gly-Arg and Leu-Gly. Electrophoresis was carried out in $10 \%$ gel containing $0.1 \%$ SDS. The electrophoretic pattern of the purified enzyme pretreated with NPGB showed only one component (Fig. 2-a). The same result was obtained by disc electrophoresis at $\mathrm{pH} 4.3$ (Fig. 2-b). These results show that the trypsin-like enzyme in Pronase was selectively bound to the immobilized RBTI and quantitatively eluted in an acidic $\mathrm{pH}$ range.

Mosolove et al. ${ }^{12)}$ reported that their preparation of S.G. trypsin possessed a specific activity (BAEE as substrate) of $130 \sim 140$ units/mg protein. They used a trypsin inhibitor from kidney beans as a ligand for the purification by affinity chromatography. Yokosawa et al. ${ }^{11)}$ also reported the purification of S.G. trypsin by affinity chromatography using arginine peptides as a ligand, though their preparation still contained a little carboxypeptidase B activity, whereas our preparation of S.G. trypsin, purified by affinity chromatography on a RBTI-Sepharose column, had a rather high specific activity and no exopeptidase activity. Therefore, it is to be concluded that our technique of affinity chromatography is highly efficient in the rapid purification of S.G. trypsin from Pronase.

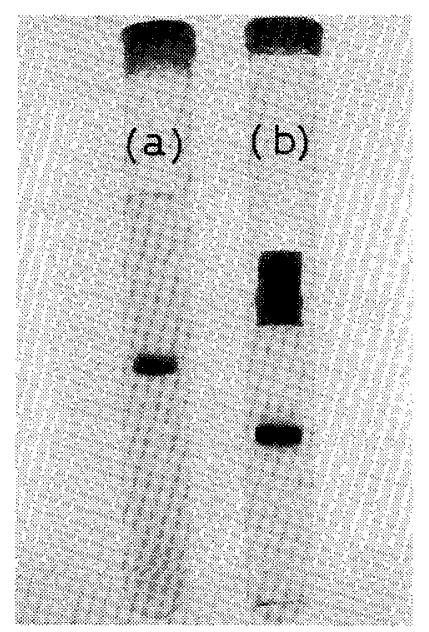

FIG. 2. SDS and Disc Electrophoreses of S. G. Trypsin Purified by Affinity Chromatography.

(a), SDS electrophoresis. Sample protein was pretreated with NPGB before the treatment with $5 \%$ 2-mercaptoethanol in $0.01 \mathrm{M} \mathrm{Na}$-phosphate buffer, pH 7.2, containing $1 \%$ SDS. Separating gel consisted of $10 \%$ acrylamide containing $0.1 \%$ SDS. The protein $(22 \mu \mathrm{g})$ was used for this electrophoresis.

(b), Disc electrophoresis. Electrophoresis was carried out in $7.5 \%$ separating gel at $\mathrm{pH} 4.3$. The protein $(31 \mu \mathrm{g})$ was used for this electrophoresis.

\section{REFERENCES}

1) Y. Narahashi, "Methods in Enzymology," Vol. XIX, ed. by G. E. Perlmann and L. Loland, Academic Press Inc., New York, N.Y., 1970, pp. 651 664 .

2) W. M. Awad, Jr., A. R. Soto, S. Siegel, W. E. Skiba, G. G. Bernstrom and M. S. Ochoa, J. Biol. Chem., 247, 4144 (1972).

3) S. Wählby and L. Engström, Biochim. Biophys. Acta, 151, 402 (1968).

4) Y. Narahashi and J. Fukunaga, J. Biochem. (Tokyo), 
66, 743 (1968).

5) R. W. Olafson and L. B. Smillie, Biochemistry, 14, 1161 (1975).

6) S. Wühlby, Biochim. Biophys. Acta, 151, 394 (1968).

7) M. Trop and Y. Birk, Biochem. J., 109, 475 (1968).

8) L. Júrasek, P. Johnson, R. W. Olafson and L. B. Smillie, Can. J. Biochem., 49, 1195 (1971).

9) B. Löfqvist and J. E. Klevhag, Acta Chem. Scand., B28, 1003 (1974).

10) K. D. Vosveck, K. F. Chow and W. M. Awad, Jr., J. Biol. Chem, 248, 6029 (1973).

11) H. Yokosawa, T. Hanba and S. Ishii, J. Biochem.
(Tokyo), 79, 757 (1976).

12) V. V. Mosolov, N. V. Fedurkina and T. A. Valueva, Biochim. Biophys. Acta, 522, 187 (1978).

13) M. Tashiro and Z. Maki, J. Nutr. Sci. Vitaminol., 25, 255 (1979).

14) B. F. Erlanger, N. Kokowsky and W. Cohen, Arch. Biochem. Biophys., 95, 271 (1961).

15) E. W. Yemm and E. C. Cocking, Analyst, 80, 209 (1955).

16) R. Axén and S. Ernback, Eur. J. Biochem., 18, 351 (1971). 